\title{
Structure of magnetron hydroxyapatite films with small stoichiometry deviation
}

\author{
I.F.Mikhailov, V.V.Starikov, A.A.Baturin \\ National Technical University "Kharkiv Polytechnical Institute", \\ 21 Frunze Str., 61002 Kharkiv, Ukraine
}

Received February 22, 2016

\begin{abstract}
Phase composition, coherence lengths and micro-strain level in hydroxyapatite films with controlled deviation from stoichiometry $(\mathrm{Ca} / \mathrm{P}=1.67)$ were measured by methods of $\mathrm{X}$-ray diffraction and X-ray fluorescent analysis. It was established that at $\mathrm{Ca} / \mathrm{P}=$ 1.6 \pm 0.03 , hydroxyapatite layers with thickness $2 \div 5 \mu \mathrm{m}$ on the niobium substrates were practically single-phase but differed by the coherence lengths and micro-strain levels for different crystallographic directions: the coherence length along [001] was commensurable with the film thickness and much exceeded the values for [101] and [111] directions. The micro-strain level $\varepsilon$ for [001] direction reached $(1.3 \div 1.7) \cdot 10^{-3}$ being by an order higher than for [101] and [111] directions. That testifies constrained growth conditions along [001] with the high homogeneity of the lattice period of the hydroxyapatite film.

Keywords: hydroxyapatite coating, chemical composition, phase composition, substructure, micro-strain.

Методами рентгеноструктурного и рентгенофлуоресцентного анализа определен фазовый состав, размеры областей когерентного рассеяния и уровень микродеформации в пленках гидроксиапатита с контролируемым отклонением от стехиометрии $(\mathrm{Ca} / \mathrm{P}=$ $1,67)$. Установлено, что при соотношении $\mathrm{Ca} / \mathrm{P}=1,67 \pm 0,03$ слои гидроксиапатита толщиной 2-5 мкм на подложках из ниобия практически однофазные, но различаются по размеру областей когерентного рассеяния и уровню микродеформации в различных кристаллографических направлениях: размер о.к.р. вдоль направления [001] соизмерим с толщиной пленки и намного превышает таковой для направлений [101] и [111] Уровень микродеформации $\varepsilon$ для направления [001] достигает $(1,3-1,7) \cdot 10^{-3}$ и на порядок превышает величину $\varepsilon$ в направлениях [101] и [111]. Это свидетельствует о стесненных условиях роста вдоль [001] при высокой однородности периода решетки пленки гидроксиапатита.
\end{abstract}

Структура магнетронних гідроксиапатитних плівок з малим відхиленням від стехіометрії.І.Ф.Михайлов, В.В.Старіков, О.А.Батурін.

Методами рентгеноструктурного й рентгенофлуоресцентного аналізу визначено фазовий склад, розміри областей когерентного розсіювання й рівень мікродеформації в плівках гідроксиапатиту з контрольованим відхиленням від стехіометрії $(\mathrm{Ca} / \mathrm{P}=1.67)$. Встановлено, що при співвідношенні $\mathrm{Ca} / \mathrm{P}=1,67 \pm 0,03$ шари гідроксиапатиту товщиною 2-5 мкм на підкладках з ніобію практично однофазні, але різняться по розміру областей когерентного розсіювання й рівню мікродеформації у різних кристалографічних напрямках: розмір о.к.p. уздовж напрямку [001] сумірний з товщиною плівки й набагато перевищує такий для напрямків [101] і [111]. Рівень мікродеформації $\varepsilon$ для напрямку [001] досягає $(1,3-1,7) \cdot 10^{-3}$ і на порядок перевищує величину $\varepsilon$ у напрямках [101] i [111]. Це свідчить про стиснені умови росту уздовж [001] при високій однорідності періоду гратки плівки гідроксиапатиту. 


\section{Introduction}

Materials based on hydroxyapatite $\mathrm{Ca}_{10}\left(\mathrm{PO}_{4}\right)_{6}(\mathrm{OH})_{2}$ are widely applied in medicine as coatings of metal implants [1] because there chemical and phase compositions are close to that of bone tissue by mineral components.

It is obviously that none of known coating deposition methods can provide absolutely homogeneous by composition and structure layers of the multi-component compounds. Small contents of extraneous phases in the coatings can result in pitting corrosion. Sometimes, such phase inhomogeneities are necessary to be created deliberately for increasing the solubility, bioresorption and osteoinduction of the hydroxyapatite coatings because pure hydroxyapatite has low bioresorption speed and weak stimulating influence on the growth of new bone tissue because of its extremely low solubility [2, 3$]$.

Taking into consideration the importance of the structural and substructure characteristics for determination of the implant operation properties, it is worth to study phase composition and substructure of films with controllable stoichiometry deviation by $\mathrm{Ca} / \mathrm{P}$ ratio. ing:

The purposes of the work are the follow-

1) creation of hydroxyapatite layers with controllable $\mathrm{Ca} / \mathrm{P}$ ratio in the range from 1.55 to 1.70 ;

2) quantitative measurements of extraneous phases;

3) determination of coherence lengths and micro-strains of the base hydroxyapatite phase in various crystallographic directions.

\section{Experimental}

Objects of the research were hydroxyapatite films deposited on niobium substrates by magnetron sputtering [4,5] from a $\mathrm{Ca}_{10}\left(\mathrm{PO}_{4}\right)_{6}(\mathrm{OH})_{2}$ (hydroxyapatite) target with stoichiometric ratio of $\mathrm{Ca} / \mathrm{P}=1.67$.

Varying the Ca/P ratio in the films was realized by change of magnetron regimes. Control of the Ca/P ratio was carried out by $\mathrm{X}$-ray fluorescent analysis (XFA) using energy-dispersive spectrometer "SPRUT" (AC Ukrrentgen, Ukraine) with SDD X-100 detector (Amptek, USA) by measuring the intensity ratio of $\mathrm{Ca}-\mathrm{K}_{\alpha}$ and $\mathrm{P}-\mathrm{K}_{\alpha}$ lines taking into account the film thickness. The scheme with a complex secondary radiator was applied to increase the spectral contrast
Table 1. Integrated intensities (number of counts accumulated for $300 \mathrm{~s}$ ) of fluorescence lines $\mathrm{Nb}-\mathrm{L}_{\alpha}$ (substrate), $\mathrm{Ca}-\mathrm{K} \alpha$ and $\mathrm{P}-\mathrm{K}_{\alpha}$ (hydroxyapatite film), film thickness $t$, and $\mathrm{Ca} / \mathrm{P}$ atomic concentration ratio

\begin{tabular}{||c|c|c|c|c|c||}
\hline Sample & $\mathrm{Nb}$ & $\mathrm{Ca}$ & $\mathrm{P}$ & $t$ & $\mathrm{Ca} / \mathrm{P}$ \\
\hline 222 & 7876 & 299439 & 77735 & 5.1 & 1.70 \\
221 & 22701 & 219092 & 68993 & 3.3 & 1.66 \\
218 & 25061 & 191238 & 66519 & 3.14 & 1.55 \\
217 & 29660 & 176075 & 66515 & 2.84 & 1.49 \\
\hline
\end{tabular}

[6]. The films thicknesses in the range from 3.0 to $5.1 \mu \mathrm{m}$ were controlled by intensity attenuation of $\mathrm{Nb}-\mathrm{L}_{\alpha}$ lines from a substrate with accuracy $\pm 0.005 \mu \mathrm{m}$ for counts accumulation from 7800 (at $t=5.1 \mu \mathrm{m}$ ) to 25060 (at $t=3.0 \mu \mathrm{m}$ ). For the pure substrate, the counts accumulation was 162100. The effect of the film thickness on the ratio of $\mathrm{Ca}-\mathrm{K}_{\alpha}$ to $\mathrm{P}-\mathrm{K}_{\alpha}$ line intensities was evaluated according to [7]. The bulk targets with the stoichiometric ratio of $\mathrm{Ca} / \mathrm{P}=1.67$ were used as standards. Time of spectra accumulation was $300 \mathrm{~s}$.

$\mathrm{X}$-ray diffraction measurements were carried out using DRON-3M diffractometer with copper anode radiation monochromatized with (002) reflection of a highly-oriented graphite crystal in the diffracted beam. A special Soller's collimator with angular divergence $0.23^{\circ}$ was placed in the front of the monochromator to increase spectrum contrast. That has allowed raising the phase analysis sensitivity by a factor of $2 \div 3$ in comparison to the usual scheme with a secondary monochromator.

Quantitative X-ray phase analysis [8] was carried out by X-ray diffraction patterns taken in $\theta-2 \theta$ scanning regime by broadening of the diffraction lines for crystallographic directions [001], [101], and [111] of the hydroxyapatite lattice. The reflections (002)-(004); (101)-(202), and (111)-(222) were analyzed. Reflection profiles were measured with step $0.02^{\circ}$ or $0.05^{\circ}$ with exposure $40 \mathrm{~s}$ or $100 \mathrm{~s}$. The standards for taking into account the geometric factor were annealed powders of metals and fullerite films.

\section{Results and discussion}

Results of the measurements for calcium/phosphorous atomic concentration ratio by fluorescence intensity from films with different thicknesses are given in Table 1. The first group of the samples had 


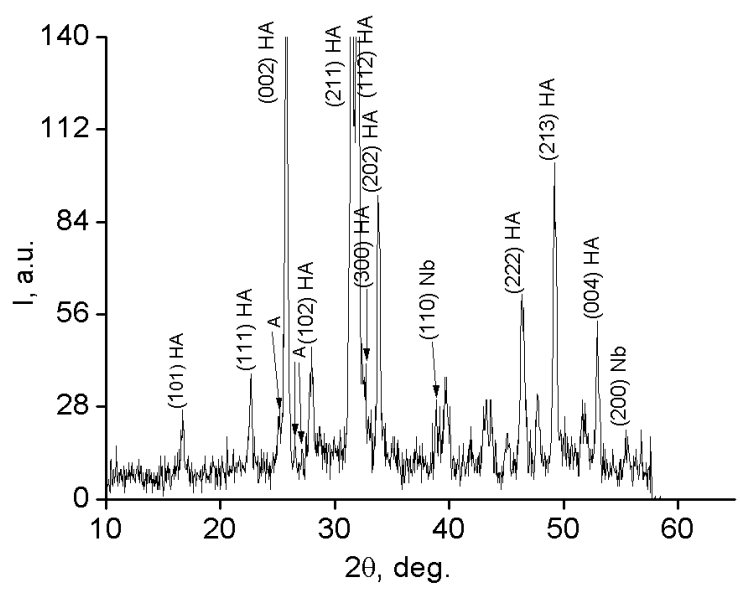

Fig. 1. Diffraction pattern of magnetron hydroxyapatite film with ratio $\mathrm{Ca} / \mathrm{P}=1.70 ; \mathrm{A}-$ reflections of extraneous phase.

the ratio $\mathrm{Ca} / \mathrm{P}=1.67$ close to nominal value for stoichiometric hydroxyapatite $\mathrm{Ca}_{10}\left(\mathrm{PO}_{4}\right)_{6}(\mathrm{OH})_{2}$, while the second being close to $\mathrm{Ca}_{3}\left(\mathrm{PO}_{4}\right)^{2}(\mathrm{Ca} / \mathrm{P}=1.5)$.

There are observed more than fifteen reflections from the hydroxyapatite phase and also two reflections from the niobium substrate in the $\mathrm{X}$-ray diffraction patterns of the samples with $\mathrm{Ca} / \mathrm{P}$ ratio close to "stoichiometric" value 1.67 (Fig. 1). The reflections intensity ratio $\mathrm{Ca}-\mathrm{K}_{\alpha} / \mathrm{P}-\mathrm{K}_{\alpha}$ is close to the tabular values; however, weak texture (001) is revealed. For some samples, very weak reflections probably belonging to $\beta-\mathrm{Ca}_{3}\left(\mathrm{PO}_{4}\right)_{2}$ phase are revealed (Fig. 1, Pos. A). The maximum possible concentration of this phase has been estimated as $3.2 \%$ for the sample with ratio of $\mathrm{Ca} / \mathrm{P}=1.7$ (Fig. 1); while at $\mathrm{Ca} / \mathrm{P}=1.66$, these reflections could not be revealed (Fig. 2) at the reached quality of the X-ray diffraction spectra. Evaluation of the maximum possible content of the extraneous phase gives $\approx 1 \%$ according to the detection limit criterion.

Thus, magnetron layers with 97-99 \% content of the base hydroxyapatite phase at $\mathrm{Ca} / \mathrm{P}$ ratios from 1.66 to 1.70 close to the stoichiometric (1.67) can be obtained.

The X-ray diffraction patterns are considerably different for the samples with ratio of $\mathrm{Ca} / \mathrm{P}=1.5$ typical for $\mathrm{Ca}_{3}\left(\mathrm{PO}_{4}\right)_{2}$ phase. In these patterns, the reflections of this phase are observed along with still strong reflections of the hydroxyapatite. That indicates heterophase structure of the film deposited by magnetron sputtering from the stoichiometric hydroxyapatite target.

High quality of the X-ray diffraction pattern has allowed to reveal reflections

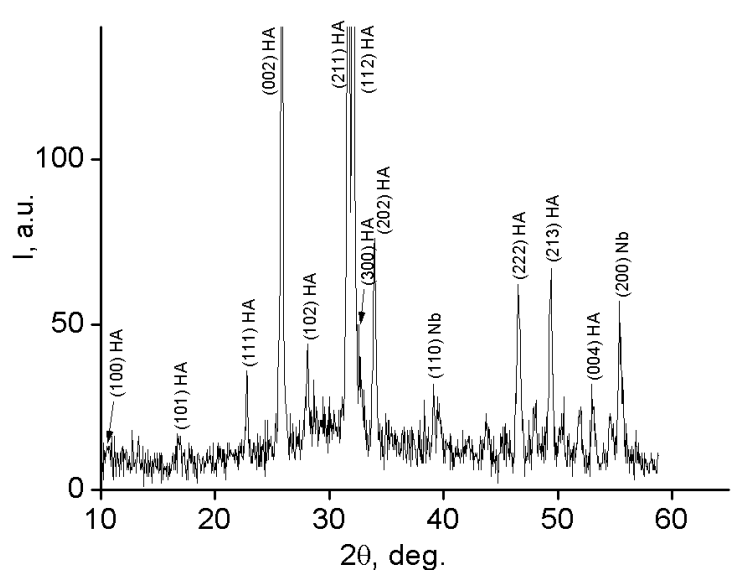

Fig. 2. Diffraction pattern of magnetron hydroxyapatite film with ratio $\mathrm{Ca} / \mathrm{P}=1.67$.

Table 2. Coherent lengths $L$ and microstrain values $\varepsilon$ measured in [001] direction for films with various $\mathrm{Ca} / \mathrm{P}$ ratios

\begin{tabular}{|c|c|c|c||}
\hline \hline Sample & Ca/P & $L, \AA$ & $\varepsilon \cdot 10^{3}$ \\
\hline 222 & 1.70 & $>3000$ & 1.35 \\
221 & 1.66 & $>3000$ & 1.70 \\
218 & 1.55 & 645 & 1.25 \\
\hline
\end{tabular}

with the big Miller's indices and to apply the method of approximation for determining the coherent lengths and micro-strains in various crystallographic directions. Practically homogeneous hydroxyapatite films with $\mathrm{Ca} / \mathrm{P}$ ratios from 1.66 to 1.70 are characterized by the large coherent lengths $L>$ $3000 \AA$ along the growth direction [001]. This means the coherent lengths in [001] direction are quite commensurable with the film thickness.

The micro-strain extent in the direction [001] is high enough being in the range of $(1.35 \div 1.70) \cdot 10^{-3}$ that testifies either constrained conditions of growth in the direction [001] or inhomogeneity of the solid solution.

In heterophase films with ratio of $\mathrm{Ca} / \mathrm{P}=$ 1.5, the coherent lengths along [001] are significantly less (Table 2), while the microstrain level being almost similar. The high micro-strains $(\varepsilon)$ along [001] can be related with the heterogeneous composition of the solid solution.

In other crystallographic directions [101] and [111], the coherent lengths are substantially lower being in the range from 460 to $830 \AA$, and the micro-strains are practically absent (Table 3). That means, the crystalline blocks are rather homogeneous by the lattice period of the basic phase, and the 
Table 3. Coherent lengths and microstrains measured in [101] and [111] crystallographic directions for single-phase hydroxyapatite films

\begin{tabular}{|c|c|c|c|c||}
\hline \multirow{2}{*}{ Sample } & \multicolumn{2}{|c|}{$(101)$ and (202) } & \multicolumn{2}{c|}{$(111)$ and (222) } \\
\cline { 2 - 5 } & $L, \AA$ & $\varepsilon \cdot 10^{3}$ & $L, \AA$ & $\varepsilon \cdot 10^{3}$ \\
\hline 222 & 830 & 0 & 460 & 0.1 \\
221 & 740 & 0.2 & $\approx 500$ & - \\
\hline
\end{tabular}

observed heterogeneity of interplanar distances along [001] is related, most likely, with the micro-strains caused by joining of the growing blocks.

\section{Conclusions}

It has been established that substructure of single-phase hydroxyapatite films differs considerably in various crystallographic directions. In growth direction [001], the coherent lengths are commensurable with the film thickness but the micro-strain level is quite high that testifies constrained condi- tions of the film growth. In [101] and [111] directions, the coherent lengths are much less $\approx 400-700 \AA$, but low level of microstrain $\left(\sim 1 \cdot 10^{-4}\right)$ indicates homogeneity of the hydroxyapatite lattice period.

\section{References}

1. L.Sun, C.C.Berndt, K.A.Gross, A.Kucuk, J. Biomed. Mater.Res., 58, 570 (2001).

2. R.Z.LeGeros, Chem. Rev., 108, 4742 (2008).

3. I.S.Lee, D.H.Kim, Y.C.Jung, C.H.Han, Biomaterials, 23, 609 (2002).

4. J.Long, L.Sim, S.Xu, K.Ostrikov, Chem.Vap. Deposition, 13, 299 (2007).

5. B.Feddes, J.G.C.Wolke, J.Jansen, A.M.Vredenberg, J.Appl.Phys., 93, 9503 (2003).

6. I.F.Mikhailov, A.A.Baturin, L.P.Fomina, $V o^{-}$ prosy atomnoy nauki i tekhniki (VANT), 2, 172 (2013).

7. V.P.Afonin, N.I.Komyak, V.P.Nikolaev, R.I.Plotnikov, X-ray Fluorescent Analysis, Nauka, Novosibirsk (1991) [in Russian].

8. S.S.Gorelik, L.N.Rastorguev, Yu.A.Skakov, X-ray and Electron-optical Analysis, Metallurgy, Moscow (1970) [in Russian]. 